\title{
PERBANDINGAN KUALITAS DEMOKRASI DALAM PERSPEKTIF KESETARAAN GENDER ANTARA INDONESIA DAN THAILAND
}

\author{
Oleh: Arin Fithriana* ${ }^{*} J_{e a n i e}$ Annissa ${ }^{*}$
}

\begin{abstract}
This study discusses the comparative quality of democracy in the perspective of gender equality between Indonesia and Thailand. Selection of study subjects based on data ranking global democracy that puts Indonesia and Thailand as a country in Southeast Asia with the quality of democracy is not far adrift. This study uses the theory of political culture for respective internal uniqueness, the quality of democracy, gender theory and comparative politics approach using Mill's Method to analyze focus of research. This study used a qualitative approach with descriptive type of analysis through literature study. The unit of analysis in this study focused on the quality of democracy in the perspective of gender equality. The unit of explanation is the comparison the quality of democracy in the perspective of gender equality Indonesia and Thailand are seen from the level of political participation of women in each country. Eachby the period between 2010 to 2014 based on internal changes that occur in both. In addition to historical comparative method is also used to acquire the common traits between the uniqueness of the community and assess long-term social change. Based on the data that has been collected relating to the history and political culture of each country, it can be said that the quality of the implementation of democracy is influenced by the historical background and internal changes. Internal change is increasingly open does not necessarily encourage democratization, it is because of the culture of political force. Eventually important role in the political system as a determinant of the quality of democracy and guarantor of democracy.
\end{abstract}

Keywords: Political culture, Quality of democracy, Gender theory, Mill's method

\section{Pendahuluan}

Implementasi demokrasi dalam

sistem politik pasca Perang Dunia ke II

menjadi keharusan suatu negara. Negara

berusaha mentrasformasi diri dengan

berbagai penyesuaian untuk mendapatkan pengakuan sebagai negara demokratis. Sebagai contoh adanya realitas affirmative action yang kemudian menjadi input dalam Undang-undang No. 8 Tahun 2012 tentang Pemilu Legislatif,

*Dosen Program Studi Hubungan Internasional FISIP Universitas Budi Luhur Jakarta. Email: arin. fithriana@budiluhur. ac. id.

-Dosen Program Studi Hubungan Internasional FISIP Universitas Budi Luhur Jakarta. Email: jeanie. annissa@budiluhur. ac.id 
mengamanatkan kewajiban partai politik peserta pemilu untuk memenuhi kuota 30 persen perempuan di daftar calon legislatif dan minimal satu perempuan diantara tiga calon legislatif. KPU (Komisi Pemilihan Umum) Indonesia juga memastikan parpol memenuhi kuota tersebut melalui Peraturan KPU No. 7 tahun 2013. Perempuan mendapat perhatian tersendiri karena hingga saat ini perempuan masih menempati posisi marginal. Posisi ini dilatar belakangi oleh banyak hal seperti budaya, agama, sosial, ekonomi dan politik. Bentuk demokrasi ideal meniadakan pembedaan tersebut dan mendorong adanya kesetaraan perempuan, terkait kesetaraan gender. Beberapa lembaga melakukan pengkajian indeks atau ranking demokrasi negara dengan melakukan pengukuran pada dimensi politik dan non politik. Pada dimensi politik pengukuran menekankan pada struktur dan fungsi sistem politik sedangkan pada non politik meliputi ekonomi, kesehatan, pendidikan, gender dan lingkungan. Pengukuran ini dengan perbandingan dimensi politik $50 \%$ sedangkan yang lainnya masing-masing $10 \%$ Democracyranking(http://democracyranking .org/wordpress/?page_id=590).

Indonesia dan Thailand merupakan contoh negara di Asia Tenggara yang masuk dalam kajian Global Democracy Ranking dengan posisi yang tidak jauh berbeda daripada negara Asia Tenggara lainnya. Meskipun data mengenai demokrasi Thailand baru tersedia tahun 2010, namun berdasarkan data tersebut demokrasi Thailand menunjukkan kondisi yang semakin meningkat. Artinya adanya perbaikan dengan implementasi demokrasi di Thailand. Demikian juga dengan Indonesia, juga menunjukkan kecenderungan yang sama.

Tabel 1. 1: Peringkat Demokrasi Global

\begin{tabular}{|c|l|l|l|l|l|}
\hline Negara & $\mathbf{2 0 1 0}$ & $\mathbf{2 0 1 1}$ & $\mathbf{2 0 1 2}$ & $\mathbf{2 0 1 3}$ & $\mathbf{2 0 1 4}$ \\
\hline Thailand & 71 & 69 & 69 & 65 & 63 \\
\hline Indonesia & 65 & 67 & 68 & 66 & 65 \\
\hline
\end{tabular}

Sumber : diolah dari http://democracyranking. org/wordpress/?page_id=14

Gender dalam demokrasi

merefleksikan dimensi yang menunjukkan tingkat keadilan di masyarakat yang berkaitan dengan kesetaraan dan kebebasan (Campbell 2008: 36). Kesetaraan dan kebebasan ini mencakup kondisi yang seimbang antara laki-laki dan perempuan untuk memenuhi hak dalam berkontribusi dan mendapatkan manfaat dari aktivitas sosial, ekonomi, budaya dan pembangunan 
politik. Penelitian hanya akan memfokuskan pada pembangunan politik saja, karena ruang lingkup yang cukup luas dalam penekanan kesetaraan gender ini. Menurut Gabriel Almond, pembangunan politik adalah upaya untuk mengembangkan kapasitas-kapasitas sistem politik dengan menggunakan pembangunan. Tujuannya adalah agar sistem politik mampu memelihara dirinya sendiri. Oleh karena itu, pembangunan politik mencakup persoalan yang luas seperti budaya politik, sosialisasi politik, partai politik, stabilitas politik, nasionalisme, institusionalisasi politik, pembangunan administrasi, hukum dan sebagainya. Dengan demikian, hal ini merupakan suatu proses perubahan yang multidimensional, dan bersifat etnosentris, artinya disesuaikan dengan kondisi dan keadaan negara tersebut. Sifat etnosentris dalam kajian demokrasi berkaitan dengan budaya politik yang berkembang. Budaya politik tidak berhenti pada satu posisi, namun mengalami perubahan yang dipengaruhi oleh faktor internal dan eksternal. Gender, dalam penelitian ini memfokuskan pada pembangunan politik, dalam kualitas demokrasi berkaitan dengan budaya politik yang ada. Berdasarkan perspektif gender tersebut akan membandingkan bagaimana kualitas demokrasi antara Thailand dan Indonesia sebagaimana dalam gambar kerangka berfikir berikut:

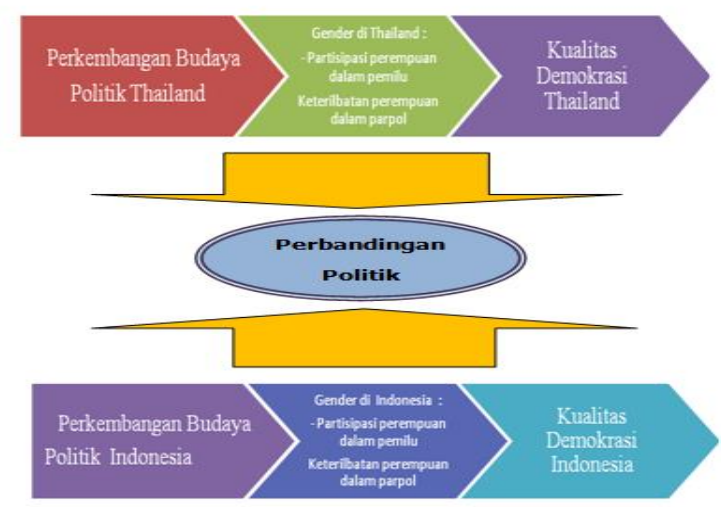

Maka yang menjadi fokus dalam penelitian ini adalah Bagaimana perbandingan kualitas demokrasi dalam perspektif gender antara Indonesia dan Thailand?.

\section{Implementasi Kesetaraan Gender dalam}

Demokrasi di Indonesia

\begin{tabular}{rrr}
\multicolumn{2}{c}{ Perempuan merupakan tonggak } \\
demokrasi yang diharapkan dapat
\end{tabular}

memberikan perubahan terhadap permasalahan kehidupan bernegara. Kehadiran perempuan di ranah politik sangat berpengaruh terhadap kerbelangsungan suara perempuan di parlemen. Perjalanan politik 
perempuan dalam proses keterwakilan di parlemen Indonesia memiliki sejarah yang panjang dan berliku. Gerakan perempuan di Indonesia dimulai sejak tahun 1928 yang ditandai dengan berlangsungnya kongres wanita Indonesia untuk meningkatkan kesadaran dan rasa nasionalisme di kalangan perempuan untuk mengambil peranan dalam pembangunan dan politik. Dalam pemilu I yang diselenggarakan tahun 1955 menempatkan 6,5 persen perempuan masuk ke dalam parlemen. Dilanjutkan kembali di tahun 1987, dengan progress peningkatan menjadi 13 persen (Khofifah Indar Parawansa 2015: 41).

Kurangnya tingkat keterwakilan politik di Indonesia dipicu oleh beberapa faktor seperti agama dan budaya. Indonesia merupakan negara yang menganut sistem nilai patriarkal yang menimbulkan persepsi pembagian peran antara laki-laki dan perempuan secara mencolok. Perempuan dibatasi pada peran domestik sehingga kesempatan perempuan dalam arena politik masih relatif kecil. Selain itu, ajaran agama Islam yang menjadi mayoritas di Indonesia dianggap kurang melibatkan perempuan dalam arena kepemimpinan sehingga semakin mempertegas gap peran laki-laki dan perempuan.
Jika melihat di masa perjuangan kemerdekaan, maka kiprah perempuan Indonesia dalam menuju kemerdekaan memiliki potensi yang sangat besar dalam membantu di medan peperangan dalam bidang logistik, kesehatan bahkan pendidikan (Tempo 29 April 1978: 55-57). Keikutsertaan perempuan memberikan kesempatan untuk menyampaikan isu-isu yang berkaitan dalam kepentingan di sekitar mereka sehingga mereka memahami apa yang dibutuhkan kaum perempuan dalam menyelesaikan masalah perempuan seharihari.

Pada sejarah pemilu di Indonesia, keterlibatan perempuan masih sangat rendah dalam ranah politik. Diketahui, dalam pemilu pertama tahun 1955, representatif perempuan banyak diwakili oleh gerakan atau organisasi seperti Gerwani dan Muslimat NU. Keikutsertaan 35 partai dan beberapa anggota kostituante dengan tingkat partisipasi rakyat yang cukup besar sebanyak 39 juta orang yang memberikan suara dengan jumlah suara yang cukup signifikan sebanyak $80 \%$ suara, perempuan hanya menempati sejumlah 17 kursi (Khofifah Indar Parawansa 2015: 43). Sedangkan di era konstituante tahun 1959, keterpilihan perempuan dalam parlemen sebanyak 25 kursi (Jurnal Sosial Demokrasi Edisi 6 Tahun 2, 2009). 
Memasuki era orde baru, keterpilihan perempuan dalam ranah politik mengalami dinamika perubahan. Dalam periode pertama di tahun 1971-1977 perempuan menempati sebanyak 36 kursi, periode kedua di tahun 1977 menempati 36 kursi dan pemilu tahun 1982 menempati 39 kursi dari total 460 kursi yang diperebutkan. Dalam periode ketiga di tahun 1987 perempuan menempati 65 kursi dari total 500 kursi yang diperebutkan, pada tahun 1992 menjadi 62 kursi, tahun 1997 sebanyak 54 kursi dan tahun 1999 menjadi 46 kursi dari total 500 kursi yang diperebutkan. Dalam pemilu 2004, anggota legislatif perempuan meningkat menjadi 61 orang dari 550 anggota yang terpilih dan di tahun 2009 berhasil menempatkan 101 anggota perempuan dari 560 anggota DPR yang terpilih (Sali Susiana 2014: 10). Sedangkan di tahun 2014 terpilih 97 orang perempuan yang menempati kursi legislatif (Yuni Retnowati 2016: 158).

Keterlibatan perempuan dalam sistem politik untuk tujuan representasi memang diperlukan, tetapi harus diimbangi dengan kualitas pengetahuan dan pengalaman politik untuk dapat diterima dan mewakili kepentingan umum masyarakat, tidak semata melihat pada jumlah kuota yyang telah disediakan bagi kelompok perempuan. Berikut adalah tabel representatif perempuan di dalam parlemen yang masih belum memenuhi kuota $30 \%$.

Tabel 4. 1

Representasi Politik Perempuan Dalam Parlemen di Indonesia.

\begin{tabular}{|l|l|l|}
\hline PERIODE & PEREMPUAN & LAKI-LAKI \\
\hline & & \\
\hline $1955-1960$ & $17(6,3 \%)$ & $272(93,7 \%)$ \\
\hline $1956-1959$ & $25(5,1 \%)$ & $488(94,9 \%)$ \\
\hline $1971-1977$ & $36(7,8 \%)$ & $460(92,2 \%)$ \\
\hline $1977-1982$ & $29(6,3 \%)$ & $460(93,7 \%)$ \\
\hline $1982-1987$ & $39(8,5 \%)$ & $460(91,5 \%)$ \\
\hline $1987-1992$ & $65(13 \%)$ & $500(87 \%)$ \\
\hline $1992-1997$ & $62(12,5 \%)$ & $500(87,5 \%)$ \\
\hline $1997-1999$ & $54(10,8 \%)$ & $500(89,2 \%)$ \\
\hline $1999-2004$ & $46(9 \%)$ & $500(91 \%)$ \\
\hline $2004-2009$ & $61(11,09 \%)$ & $489(88,9 \%)$ \\
\hline
\end{tabular}

Sumber: Nur Iman Subono (2009: 59). 
Jika mengetahui berdasarkan aturan KPU No. 7 Tahun 2013 tentang pencalonan legislatif pasal 11 menegaskan keterlibatan perempuan sebanyak $30 \%$ yang merupakan bentuk affirmative action dalam memberikan kesempatan kepada perempuan untuk terlibat dalam kegiatan politik dan pembuatan kebijakan umum. Selain itu, penetapan kuota perempuan sebanyak $30 \%$ juga disahkan melalui UU Pemilu No. 12 Tahun 2003 dalam pasal 65 (1) ang berbunyi bahwa Partai Politik peserta Pemilu dapat mengajukan calon DPR, DPRD Provinsi dan DPRD Kabupaten/ Kota untuk setiap daerah pemilihan dengan memperhatikan keterwakilan perempuan sekurangkurangnya 30\% (Yuni Retnowati 2016: 156).

Keterlibatan perempuan dalam pemenuhan affirmative action telah diperkuat melalui Undang-Undang Nomor 10 tahun 2008 yang memuat kebijakan keterlibatan perempuan di ruang politik sebanyak $30 \%$, sehingga perempuan memiliki peran politik dalam membuat kebijakan bagi masyarakat. Di tahun 2004 belum ada sanksi maupun teguran bagi partai politik yang belum memenuhi jumlah kuota perempuan sebanyak 30\%. Namun tahun 2009, setiap partai politik yang belum memenuhi syarat kuota $30 \%$ harus memberikan pengumuman melalui media agar tidak dicoret dalam bursa peserta pemilu. Masalah ini telah termaktub di dalam Peraturan KPU No. 7 Tahun 2013 pasal 11. Dalam arti lain, terdapat 1 kandidat perempuan dari 3 (tiga) kandidat yang dicalonkan oleh masing-masing partai politik (Yuni Retnowati 2016: 156).

Dengan demikian, partisipasi politik perempuan di Indonesia telah diperkuat melalui 3 (tiga) peraturan yang menguatkan dengan menempatkan kuota perempuan dalam ranah politik. Keterbatasan budaya dan agama seharusnya tidak menjadi kelemahan bagi perempuan dalam meningkatkan kemampuan membentuk keputusan politik, sehingga bisa merepresentasikan kebutuhan hak-hak perempuan. Perempuan memiliki sisi kepribadian yang menarik dengan gaya dan karakter kepemimpinan berbeda dengan lakilaki.

Meskipun begitu, ketertarikan perempuan terhadap politik masih rendah. Faktor agama, budaya, dan lingkungan memberikan keterbatasan bagi perempuan. Peran domestik perempuan yang diperkuat oleh nilai-nilai budaya patriaki masih menjadi bayang-bayang perempuan terhadap perkembangan kualitas diri untuk memasuki wilayah publik. Kemudian, lingkungan menjadi wujud penghakiman terhadap perempuan yang tidak lagi mengikuti adat 
budaya yang secara psoikologis membatasi gerak dan peran perempuan, sehingga masih sulit menunjukan keberanian dalam memberikan gagasan dan ide (Yuni Retnowati 2016: 156).

Selain itu, proses pemberdayaan terhadap perempuan secara langsung maupun tidak belum mencapai tingkat maksimal sehingga masih banyak perempuan yang belum bisa merumuskan kepentingankepentingan mereka sendiri. Isu-isu sosial yang berkaitan dengan kebutuhan perempuan masih sering terabaikan, padahal perempuan masih terlibat dalam aktivitas sosial yang mewujudkan rasa social connectivity awareness yang tinggi. Oleh karena itu, dapat diagregasikan kepentingan tersebut ke ranah politik.

\section{Implementasi Kesetaraan Gender Dalam Demokrasi Di Thailand}

Tingkat partisipasi perempuan pada politik di Thailand tergolong rendah di negara anggota ASEAN. Sebagaimana dideskripsikan pada budaya politik Thailand, dipengaruhi oleh budaya China dan India yang menempatkan perempuan pada posisi inferior dengan hak yang terbatas. Perempuan menjadi "harta" kepemilikan keluarga suami dan berkewajiban melayani mereka (Orapin Sopchokchai 1998: 11-12).
Thailand memiliki sejarah panjang juga berkaitan dengan partisipasi perempuan dalam politik, baik ditingkat lokal maupun tingkat nasional. Perempuan Thailand secara tradisional mengabdikan diri pada raja dan keluarga bangsawan. Peran perempuan dalam politik terbatasi karena gendernya. Namun demikian bukan berarti tidak ada pergerakan sama sekali dalam kehidupan sosial masyarakat Thailand. Perubahan terjadi pada Raja Rama IV dan VI di tahun 1888 dengan adanya koran perempuan pertama "Naree Rom", kemudian diikuti dengan "Kulasatree". Secara tidak langsung artikel tersebut menunjukkan kepentingan perempuan dalam sosial dan politik. Dengan adanya pengaruh barat, mulai ada perhatian terhadap pendidikan bagi anak perempuan Thailand. Pada perempuan yang terlahir dari keluarga kelas atas, mereka bergabung dengan keluarga kerajaan.

Pada tahun 1901, sekolah perempuan pertama didirikan, dan dua puluh enam tahun kemudian, perempuan pertama kali terdaftar sebagai mahasiswi di Universitas Chulalongkorn. Membutuhkan waktu yang cukup lama bagi perempuan Thailand untuk menunjukkan jati dirinya. Karena setelah ada perempuan dengan tingkat pendidikan tinggi juga tidak langsung terserap dan mampu meningkatkan partisipasi politiknya. Hal ini 
salah satunya kurangnya dukungan dari konstitusi sebagai legal formal perempuan dalam beraktivitas. Konstitusi pertama tahun 1932 masih menunjukkan inferioritas perempuan, meskipun dalam konstitusi sudah tertulis bahwa ada kesetaraan hak antara lakilaki dan perempuan, namun implementasinya masih belum terwujud.

Hal ini karena aturan dibawahnya masih memberikan deskriminasi terhadap hak perempuan. Konstitusi tahun 1974 mulai ada sedikit perubahan dengan adanya amandemen pada undang-undang berdasarkan tuntutan dari berbagai pihak, seperti kelonggaran kepemilikan paspor, posisi perempuan di Militer dan pemerintahan. Persentase partisipasi perempuan dalam parlemen Thailand jika dilihat sejak tahun 1933 hingga 1996 pada table 4.2 dibawah menunjukkan perbandingan yang cukup tinggi jika dibandingkan dengan partisipasi laki-laki (Orapin Sopchokchai 1998: 13-14). Pada tabel tersebut juga dapat dilihat jika perbandingan antara jumlah kandidat perempuan dan laki-laki juga cukup tinggi.

Tabel 4. 2 : Jumlah Kandidat Laki-Laki dan Perempuan dan Anggota Parlemen Thailand dari tahun 1933 - 1996

\begin{tabular}{|c|c|c|c|c|c|c|c|}
\hline \multirow[b]{2}{*}{ No. } & \multirow[b]{2}{*}{ Blection Date } & \multicolumn{3}{|c|}{ Number of Candidates } & \multicolumn{3}{|c|}{ Number of MPs } \\
\hline & & Total & Male & Female. & Total & Male & Female \\
\hline 1 & 15 November 1933 & na & na & na & 78 & na & na \\
\hline 2 & 7 November 1937 & na & na & na & 91 & na & na \\
\hline 3 & 12 November 1938 & na & na & na & 91 & na & na \\
\hline 4 & 6 January 1946 & na & na & na & 96 & na & na \\
\hline 5 & 29 January 1948 & na & na & na & 99 & na & na \\
\hline 6 & 26 February 1952 & $\mathrm{na}$ & na & na & 123 & 119 & 4 \\
\hline 7 & 26 February 1957 & 966 & na & na & 160 & 159 & 1 \\
\hline 8 & 15 February 1957 & 813 & $\mathrm{na}$ & $\mathrm{na}$ & 160 & 156 & 4 \\
\hline 9 & 10 February 1969 & 1.253 & 1.226 & 27 & 219 & 214 & 5 \\
\hline 10 & 26 January 1975 & 2,199 & na & na & 269 & 266 & 3 \\
\hline 11 & 4 April 1976 & 2.329 & na & na & 279 & 272 & 7 \\
\hline 12 & 22 April 1979 & 1,626 & na & na & 301 & 292 & 9 \\
\hline 13 & 18 April 1983 & 1,880 & 1.826 & 54 & 324 & 311 & 13 \\
\hline 14 & 27 July 1986 & 3,811 & 3.449 & 362 & 347 & 335 & 12 \\
\hline 15 & 24 July 1988 & 3,612 & 3,246 & 366 & 357 & 347 & 10 \\
\hline 16 & 22 March 1992 & 2,954 & 2.742 & 212 & 360 & 348 & 12 \\
\hline 17 & 13 September 1992 & 2,417 & 2,175 & 242 & 360 & 345 & 15 \\
\hline 18 & 2 July 1995 & 2,372 & 2,130 & 242 & 391 & 367 & 24 \\
\hline 19 & 17 November 1996 & 2,310 & 1,950 & 360 & 393 & 371 & 22 \\
\hline
\end{tabular}

Notes: na $=$ not available; $\mathrm{MPs}=$ members of parliament.

Source: Election Division, Department of Local Administration, Ministry of Interior.

Berdasarkan data pada tabel diatas terlihat jarak antara beberapa pemilu cukup dekat. Hal ini menunjukkan bahwa konflik kepentingan politik di Thailand cukup tinggi. Parlemen yang telah terpilih dan disahkan belum lagi bekerja sudah dibubarkan. 
Namun kondisi ini tidak diikuti dengan peningkatan signifikan dari partisipasi perempuan dalam parleman. Misalnya saja pada tahun 1996 perempuan hanya mendapatkan kursi sekitar 5,6\% dari total kursi yang ada. Pergantian kepemimpinan Thailand menjadi perhatian internasional, sehingga banyak kajian yang menbahas tentang perpolitikan Thailand. Kajian ini secara tidak langsung juga menjadi bagian dari evaluasi diri masyarakat Thailand. Pada sisi lain, pembangunan ekonomi Thailand menempatkan Thailand sebagai salah satu negara industri baru di Asia. Pergolakan politik di Thailand seakan bukan menjadi penghalang bagi aktivitas ekonomi Thailand, seperti pada sektor pariwisata dan pertanian.
Hal ini menjadi keuntungan tersendiri bagi Thailand, sehingga secara tidak langsung juga mendorong peningkatan kualitas kehidupan masyarakat Thailand. Termasuk peningkatan pendidikan perempuan. Seiring dengan peningkatan pendidikan perempuan, dalam hal ini adanya akses pendidikan pada perempuan dan reformasi politik, mulai ada partisipasi perempuan dalam politik. Reformasi ini tercantum dalam konstitusi tahun 1997 dimana secara jelas perempuan berkesempatan duduk dalam parlemen (Romanov 2012: 55). Penegasan konstitusi ini masih belum menyebutkan batas kuota perempuan di Parlemen, sehingga persentase perempuan di Thailand sejak diberlakukan konstitusi tersebut masih dibawah 10 persen. Ini terlihat dalam tabel berikut:

\section{Grafik 4. 1 : Persentase perempuan dalam Parlemen Nasional Thailand (Romanov} 2012: 55)

Figure 13: Percentage of seats held by women in national parliaments

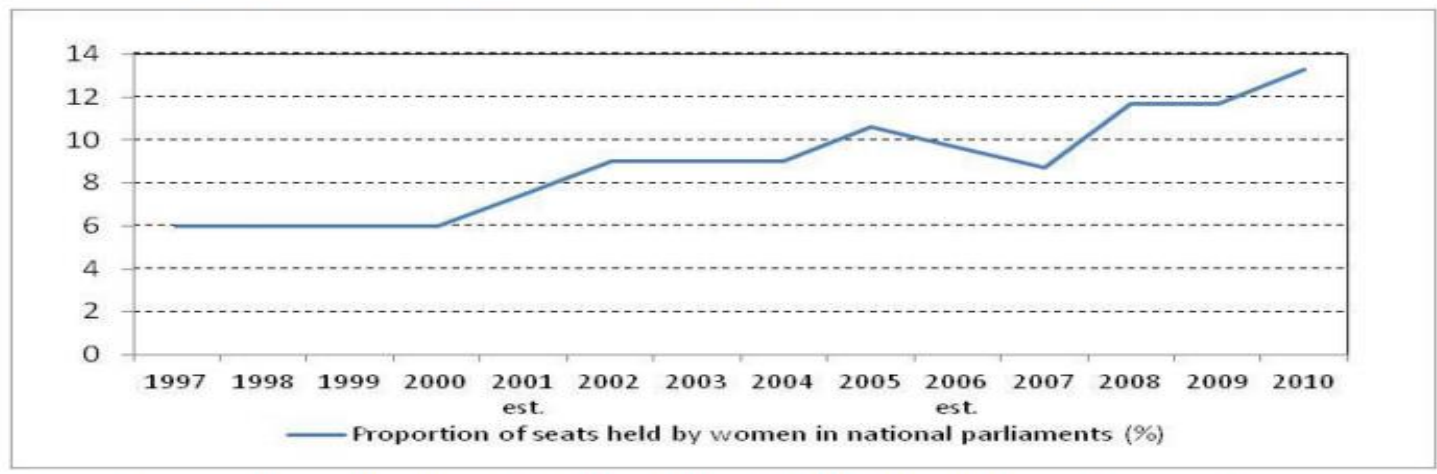

Source: Created by author based on World Bank (2011) World Development Indicators (as posted on the World Bank website; downloaded on June 7, 2011). 
Kondisi perpolitikan Thailand yang masih tidak stabil pada akhirnya mendorong perubahan konstitusi, sehingga pada tahun 2007 disahkan konstitusi baru Thailand. Namun perwakilan perempuan masih rendah, demikian juga dalam administrasi publik yang lebih tinggi dan pengadilan. Konstitusi tersebut tidak mengatur secara tegas tentang kuota perempuan di Parlemen. Demikian juga dengan Organic Act on Political Parties B. E. 2550 (2007) tentang partai politik Thailand dan The Organic Act on Election Commission B. E. 2550 tentang pemilihan umum Thailand tidak menyebutkan ketentuan kuota perempuan sebagai persyaratan. Ketentuan kuota hanya ditetapkan secara sukarela oleh Partai Politik yang mulai memperhatikan aspek gender. Satu-satunya partai yang menetapkan kuota hanyalah partai Demokrat (Pak Prachatipol) dengan target kandidat perempuan sebesar 30 persen. Sehingga Thailand merupakan negara voluntary party quota dalam penetapan partisipasi perempuannya.

Penduduk Thailand sebanyak 67 juta jiwa Sebagaimana disebutkan dalam budaya politik Thailand, bahwa perempuan Thailand berada pada posisi inferior, menempatkan perempuan pada posisi yang tidak penting. Sekitar 70. 000 posisi politik dikota dan di desa Thailand, perempuan hanya berpartisipasi sebanyak 4\% (http://www. th. undp.org/content/thailand/en/./home/ourwor k/social_advocacy/successstories/advocacyfor-political-equality-puts-undp-in-nationalspotlight. htm) Mulai pada Desember 2010 UNDP Thailand dan Kementrian Pembangunan Sosial dan Keamanan Manusia mengenalkan sistem quota pada pemilu. Penegenalan ini juga dilakukan survey yang hasilnya menunjukkan bahwa $86 \%$ laki-laki setuju bahwa sistem quota gender akan membantu meningkatkan partisipasi perempuan.

Tipe voluntary political party quota ini juga berlaku pada pemilihan umum tahun 2011. Dari seluruh anggota dewan perwakilan, perempuan hanya berjumlah 79 orang atau 16 persen. Secara terperinci perwakilan perempuan di Thailand mencapai $15 \%$ pada MPs, $16 \%$ senator, 17\% PNS. Pada tahun 2008, 9,4\% perempuan terpilih sebagai PNS (Pegawai Negeri Sipil). Pada sektor swasta, kondisi menjadi lebih baik dengan adanya peningkatan menjadi $35,3 \%$. Pada bulan Juli 2011 Thailand memilih Perdana Menteri perempuan untuk pertama kalinya - Yingluck Shinawarta. Dengan moment ini kelompok perempuan mengharapkan perubahan signifikan yang mendorong inisiatif pemberdayaan perempuan terutama dalam peningkatan 
perwakilan perempuan dalam pembuatan keputusan.

Perubahan konstitusi Thailand pada tahun 2007 didalamnya memuat keseimbangan hak antara laki-laki dan perempuan. Dalam amandemen tersebut dibuat untuk memperbaiki kemampuan perempuan dalam mengklaim hak mereka. Pada pemilu 2011 Thailand memperebutkan 500 kursi yang terdiri dari 375 kursi untuk konstitensi list dan 125 kursi party list. Constituency list sama dengan daerah pemilihan (dapil) (Aim Sinpeng 2015). Setiap dapil hanya akan diwakili oleh satu orang anggota parlemen. Dan 1 partai hanya bisa mendaftarkan satu kandidat pada konstituensi. Untuk partai list, satu partai bisa mendaftarkan maksimal 125 kandidat. Ketentuan ini didasarkan pada amandemen konstitusi tahun 2007 pasal 93-98 dengan amandemen terakhir 11 Februari 2011 (http://www. ipu. org/parline-e/reports/ThaiHR_B. htm).

Sistem ini serupa dengan sistem pemilu legislatif di Indonesia sampai tahun 2004. Semakin kecil nomor kandidat, maka semakin besar kemungkinan kandidat tersebut menjadi anggota parlemen/DPR (Rathasapha). Setelah 500 anggota parlemen terpilih, maka para anggota Parlemen memilih perdana menteri yang masa waktu memerintah 4 tahun. Pemilu tahun 2011 diikuti oleh 40 partai politik dengan partai besar antara lain; Pheu Thai memenangi 265 kursi(204 berasaskan kawasan +61 daftar partai), Demokrat $159(115+44)$, Bhumjai Thai $34(29+5)$, Chartthaipattana $19(15+$ 4), Palung Chon $7(6+1)$, Chart Pattana Puea Pandin $7(5+2)$, Cinta Thailand 4 (daftar partai saja), Matubhum $2(1+1)$, Demokrat Baru 1 (daftar partai) dan Mahachon (daftar partai) (http://www. republika. co. $\mathrm{id} /$ berita/internasional/asean/13/12/28/myiba r-pemilu-thailand-2-februari-diikuti-53partai). Setelah Yingluck berkuasa sebagai PM, krisis politik Thailand masih juga berlanjut sehingga Yingluck membubarkan majelis rendah

Thailand merupakan negara dengan tingkat pergantian kepemimpinan yang cukup tinggi. Pemilu pada tahun 2011 merupakan pemilu ke 26 sejak tahun 1932 mengakhiri tujuh abad masa monarkhi. Sepanjang sejarah telah terjadi 18 kali kudeta militer, dan 17 kali perubahan konstitusi. Meskipun urbanisasi sering dikaitkan dengan kemiskinan dan mobilisasi politik rendah dalam deprivasi ekonomi, namun urbanisasi juga mempermudah akses terhadap tempat pemungutan suara dan memberi peluang bagi pemilih untuk mendapatkan akses informasi politik, dan bahkan partai politik lebih mudah 
dalam memobilisasi konstituennya (Schraufnagel, Buehler, Lowry-Fritz 2014: 1) Krisis Politik di Thailand yang terpajang dimulai ketika massa yang tergabung dalam Aliansi Rakyat untuk Demokrasi menuntut turunnya perdana menteri Thaksin Shinawatra pada pemerintahan kedua tahun 2006, dilanjutkan dengan tuntutan terhadap Samak Sundaravej tahun 2008, dan kemudian Somchai Wongsawat karena dianggap telah menyalahgunakan kekuasaan dan penyelewengan.

Pada pemilu 2 February 2014, Yingluck memenangi pemilu yang diboikot oleh partai Demokrat. Pada pemilu tersebut tercatat jumlah pemilih sebanyak 43. 024 . 042 jiwa dan yang melakukan pemilihan sebanyak 20. 129. 976 jiwa (46,79\%). Pada pemilu ini mulai dikenalkan golongan putih yang kemudian disebut "no vote" yang didukung oleh Partai Demokrat sebagai oposisi. No vote menjadi pilihan tersendiri dalam pemilu tahun 2014 (Thailand General Election 2014: 25). Yingluck digantikan oleh Niwatthamrong Boonsongpaisan (sebagai pelaksana tugas) pada 7 Mei 2014 hingga dialihkan pada kekuasaan militer dibawah Jenderal Prayuth Chan-ocha dengan rencana pemilu Februari 2016 (http://www. theglobal-review.com/content_detail. php?lang=id\&id $=5813 \&$ type $=2 \#$. VoHdTU9u1s).

Analisa Perbandingan Kualitas

Demokrasi dalam Perspektif Gender Antara Indonesia dan Thailand

Suatu hal yang perlu diperhatikan dalam analisa pada penelitian perbandingan politik bahwa teori yang digunakan dalam menganalisa hanyalah sebagai landasan untuk membuat generalisasi terbatas dan bukan untuk menguji teori. Sedangkan yang menjadi keunggulannya adalah mengembangkan perspektif dengan memfokuskan pada persamaan dan perbedaan unit-unit analisis. Berdasarkan penjelasan dalam sub bab-sub bab sebelumnya, menunjukan kedudukan perempuan masih sangat rendah dalam menduduki jabatan-jabatan publik di ranah politik. Di Indonesia maupun Thailand interval keikutsertaan perempuan dalam demokrasi saling kompetitif. Dalam peringkat demokrasi Thailand mengungguli dalam kurun waktu terakhir, sedangkan Indonesia mengalami kenaikan yang signifikan khususnya di tahun 2012.

Jika dilihat berdasarkan data, menunjukan bahwa peringkat demokrasi Indonesia secara rata-rata berada lebih tinggi daripada Thailand (semakin kecil peringkat, semakin baik kondisi demokrasi). Indonesia 66,2 dan 
Thailand 67,4. Hal ini juga dapat dilihat kualitas demokrasi (Data Tabel 2) dalam kualitas sistem politiknya. Sistem politik dalam peringkat demokrasi menempati porsi $50 \%$ dari total penghitungan

Tabel 4. 3 : Perbandingan Tingkat Demokrasi Indonesia-Thailand Berdasarkan Keterwakilan Perempuan

\begin{tabular}{|c|c|c|c|c|c|c|c|c|c|c|}
\hline \multirow[t]{2}{*}{ Ketentuan } & \multicolumn{5}{|c|}{ Indonesia } & \multicolumn{5}{|c|}{ Thailand } \\
\hline & 2010 & 2011 & 2012 & 2013 & 2014 & 2010 & 2011 & 2012 & 2013 & 2014 \\
\hline $\begin{array}{l}\text { Peringkat } \\
\text { demokrasi }\end{array}$ & 65 & 67 & 68 & 66 & 65 & 71 & 69 & 69 & 65 & 63 \\
\hline $\begin{array}{l}\% \text { kualitas } \\
\text { gender dalam } \\
\text { demokrasi }\end{array}$ & 56,5 & 60,9 & 61,1 & 63,1 & 59,7 & 56,3 & 62,1 & 63,3 & 66,2 & 64 \\
\hline $\begin{array}{l}\text { \% Kualitas } \\
\text { Sistem Politik }\end{array}$ & 50,3 & 56,7 & 57,1 & 58 & 54 & 39,9 & 45,3 & 48 & 52,1 & 50 \\
\hline $\begin{array}{l}\text { Ketentuan } \\
\text { kuota } \\
\text { perempuan }\end{array}$ & $\begin{array}{l}\text { Legisl } \\
\text { ated }\end{array}$ & & & & & $\begin{array}{l}\text { Volun } \\
\text { tary } \\
\text { party } \\
\text { quota }\end{array}$ & & & & \\
\hline $\begin{array}{l}\text { \%perempuan } \\
\text { di parlemen }\end{array}$ & 18 & 18,2 & 18,6 & 18,6 & 16,9 & 13,3 & 15,8 & 15,8 & 15,8 & 6,1 \\
\hline $\begin{array}{l}\text { Perempuan } \\
\text { sebagai } \\
\text { legislator }\end{array}$ & $\begin{array}{l}21,21 \\
5\end{array}$ & - & - & $\begin{array}{l}23,15 \\
2\end{array}$ & - & 25,76 & $\begin{array}{l}25,06 \\
9\end{array}$ & - & - & - \\
\hline $\begin{array}{l}\text { \%Perempuan } \\
\text { sebagai } \\
\text { menteri }\end{array}$ & 14,3 & - & 11,4 & - & 11,8 & 12,5 & - & 8,7 & - & 8,3 \\
\hline
\end{tabular}


Jika dilihat berdasarkan data: peringkat demokrasi Indonesia secara ratarata berada lebih tinggi daripada Thailand (semakin kecil peringkat, semakin baik kondisi demokrasi) Indonesia 66,2 dan Thailand 67,4 . Hal ini juga dapat dilihat dalam kualitas system politiknya. System politik dalam peringkat demokrasi menempati porsi $50 \%$ dari total penghitungan kualitas demokrasi. Pada peringkat kualitas demokrasi, semakin besar persentasenya, maka semakin baik kualitas. Indonesia secara rata-rata lebih baik kualitas politiknya sebesar 18,40 persen antara tahun 2010-2015, sedangkan Thailand 15,68 persen pada periode yang sama. Telah dijelaskan bahwa dalam keterwakilan perempuan di Indonesia telah Dapat dikatakan meskipun kualitas gender dalam demokrasi di Thailand lebih tinggi daripada Indonesia, namun keterlibatan perempuan dalam parlemen dan pemerintahan di Indonesia lebih tinggi. Hal ini dikarenakan stabilitas system politik Indonesia yang lebih baik dengan termasuk implementasi konstitusi yang mengatur keterlibatan perempuan dalam parlemen diatur secara jelas. Lain hal nya dengan Thailand, konstitusi dan undang-undang tentang pemilu dan parpol belum/tidak mengatur secara tegas kuota perempuan dalam parlemen. Kuota hanya bersifat sukarela oleh partai politik, dalam hal ini diintegrasikan oleh serangkaian peraturan yang mengatur tentang jumlah keterwakilan perempuan sebesar $30 \%$. Pemerintahan Indonesia.

Namun demikian persentase kualitas gender dalam demokrasi, Thailand menunjukkan persentase angka yang lebih tinggi daripada Indonesia. Persentase kualitas gender hanya 10persen dari total penghitungan kualitas demokrasi dan ini tidak hanya ditunjukkan dengan keterlibatan perempuan dalam politik, namun juga dilihat dari keterlibatan perempuan dalam layanan pendidikan, kesehatan dan ekonomi. Angka ini berkesinambungan dengan indeks kualitas hidup manusia yang berkaitan dengan pembangunan.

hanya partai Demokrat saja yang mensyaratkan kuota 30 persen untuk anggota partai.

Jadi dapat dikatakan pembangunan materi di Thailand telah mampu meningkatkan kualitas gender di Thailand dengan adanya keterlibatan perempuan dalam layanan pendidikan, kesehatan dan ekonomi. Sedangkan pembangunan immateri, dalam hal ini adalah system politik, tidak cukup signifikan dalam meningkatkan kualitas gender di Thailand. Hal ini sebaliknya dengan Indonesia, bahwa kualitas gender mengalami peningkatan dengan adanya kepastian 
hukum akan keterlibatan dan peran perempuan dibawah stabilitas pelaksanaan sistem politik.

Di Indonesia, keterwakilan perempuan di dalam ranah politik seringkali dibatasi oleh parpol. Menurut Notosusanto secara spesifik terdapat kendala ataupun hambatan bagi perempuan yang berusaha memajukan diri serta meningkatkan keefektivitasan di dalam tubuh parpol, diantaranya adalah masih rendahnya sosialisasi politik terhadap perempuan sehingga sedikit sekali jumlah perempuan yang terkaderisasi; kepemimpinan partai politik yang cenderung didominasi oleh kelompok lakilaki sehingga kecenderung menominasikan laki-laki lebih besar dan berpotensi menang; adanya penyeleksian kandidat perempuan yang hanya memiliki afiliasi dengan penguasa sehingga partai politik kurang transparan dalam menjalankan fungsinya untuk melakukan proses rekrutmen politik; kekuatan dana yang dimiliki perempuan masih sangat sedikit sedangkan sebagian besar partai politik masih melimpahkan sumber dana anggaran politik secara independen sedangkan biaya politik membutuhkan anggaran dana yang luar biasa besar; dan terakhir adalah kurangnya mobilisasi perempuan dan ketidakmampuan untuk saling mendukung sehingga menempatkan perempuan dalam posisi rawan kalah ketika mereka harus proaktif dalam memperjuangkan hak-hak hidupnya (Yuni Retnowati 2016: 159-160).

\section{Kesimpulan}

Pada perbandingan kualitas demokrasi antara Indonesia dan Thailand dalam perspektif gender dengan menggunakan Mill's method, menunjukkan bahwa secara rata-rata kualitas gender Indonesia antara tahun 2010 sampai 2014 lebih rendah daripada Thailand. Namun demikian, bukan berarti perempuan di Thailand mempunyai tingkat partisipasi politik yang lebih tinggi daripada Indonesia. Hal ini terlihat dalam data bahwa persentase perempuan di Parlemen Thailand, pada tingkat pembuat keputusan dan jajaran pemerintah (menteri) lebih kecil daripada Indonesia. Hal yang perlu dicatat bahwa kualitas gender tidak hanya ditentukan oleh keberadaan perempuan dalam partisipasi politik.

Kondisi ini mengacu pada kualitas gender sebagaimana UNDP dalam Gender Empowerment Measure (GEM) yang memiliki tiga indikator; yaitu 1) proporsi kursi perempuan dalam parlemen, 2) persentase perempuan dalam posisi pembuatan keputusan bidang ekonomi (termasuk administratif, managerial, profesional dan teknis). 3) Andil perempuan dalam pendapatan. Indonesia unggul pada indikator pertama, namun pada indikator kedua dan ketiga tidak, sehingga 
inilah yang menunjukkan keunggulan kualitas gender Thailand.

Jika dilihat dari sistem politiknya, Indonesia cenderung lebih stabil dengan dengan tingkat yang lebih tinggi daripada Thailand. kestabilan ini menjadi satu satu penjamin berjalannya demokrasi di Indonesia dengan adanya pelaksanaan aturan dan hukum. Pada penelitian ini terlihat bahwa adanya ketetapan kuota perempuan dalam parlemen yang dimiliki Indonesia menjadi salah satu kunci kualitas demokrasi Indonesia. Hal yang sebaliknya di Thailand, dengan tidak adanya jaminan konstitusi tentang kuota perempuan, maka partisipasi perempuan dalam politik rendah meskipun kualitas gender semakin baik.

Menggunakan Mill's method, ada kesamaan (method of agreement) antara Indonesia dan Thailand, yaitu sebagai negara demokrasi di Asia Tenggara dengan perkembangan budaya politik yang dipengaruhi oleh feodalisme. Disisi lain persamaan tersebut juga menghasilkan perbedaan (method of difference) yang menjadi perbandingan dan analisa bahwa pada perkembangannya persamaan mengalami perubahan seiring pengaruh berkembangnya budaya politik dalam perilaku politik. Ini terlihat bahwa sistem politik Indonesia cenderung stabil dan menghasilkan budaya politik partisipan termasuk dengan adanya ketentuan kuota perempuan di Parlemen sebesar 30 persen.
Sedangkan di Thailand budaya politik masih cenderung feodal dengan superioritasnya belum menetapkan jumlah kuota perempuan dalam parlemen. Kuota masih bersifat kesukarelaan partai, dalam hal ini hanya partai Demokrat yang telah membuat kuota 30 persen bagi partainya. Dapat dikatakan ini merupakan bentuk melanggengkan budaya superior atas lakilaki terhadap perempuan meskipun perempuan Thailand telah mengalami peningkatan kualitas.

Sedangkan di Indonesia, tantangan budaya dan agama masih menjadi jurang pembeda yang sangat besar bagi keterlibatan perempuan di ranah politik. Selain itu, kepemimpinan perempuan masih belum lumrah untuk penerapan di Indonesia sehingga walaupun serangkaian konstitusi telah mengatur pembagian kuota perempuan di arena politik tetapi implementasi menunjukan masih belum sepenuhnya partai politik memfasilitasi dan mendukung perempuan dalam aktivitas politiknya.

Nilai superioritas laki-laki dan nilainilai feodalistik di Indonesia masih menjadi penghambat terselenggaranya kualitas demokrasi yang sehat di dalam sistem perpolitikan di Indonesia. Keterlibatan perempuan yang rendah tidak dapat menghantarkan perempuan dalam menyelesaikan permasalahan isu-isu yang berkaitan dengan kebutuhan perempuan, 
sehingga edukasi dan pembimbingan politik bagi perempuan sangat dibutuhkan agar kaum perempuan berani tampil dalam ranah kepemimpinan yang selama ini dikuasai oleh kaum laki-laki. Dapat diketahui bahwa keterlibatan perempuan dalam pertumbuhan demokrasi mengalami perubahan walaupun masih jauh dari

\section{DAFTAR PUSTAKA}

Campbell, David F. J. , 2008, The Basic Concept for the Democracy Ranking of the Quality of Democracy, Vienna: University of Klagenfurt

Chilcote, Ronald H. , 2007, Terj. Haris Munandar, Dudy Priatna, Teori Perbandingan Politik: Penelusuran Paradigma, Jakarta: PT. Raja Grafindo Persada

Cullell, Vargas, Jorge and Osvaldo Lazzetta (ed) 2004, The Quality of Democracy: Theory and Applications, University of Notre Dame Press

Freedman, Amy L. ,2006, PoliticalChange and Consolidation: Democracy's Rocky Road in Thailand, Indonesia, South Korea, and Malaysia, New York: Palgrave

Ji Ungpakorn, Giles, 2007, A Coup for the Rich; Thailand's Political Crisis, Worker Democracy Publishing: Bangkok

J Wiarda, Howard, Esther M Skelley, 2007, Compartaive politics : approaches and issues, USA : Rowman \& Littlefield Publisher Inc. realisasi, tetapi peningkatan pertumbuhan perempuan di ranah politik semakin bertambah dan mengalami peningkatan. Dengan demikian, kualitas demokrasi dalam indikator gender mengalami laju perubahan walaupun masih dalam kategori rendah.

Mulder, Niels, 2000, Inside Thai Society, Chiang Mai: Silkworm Books

Mas'oed, Mochtar Colin MacAndrews, 2000, Perbandingan Sistem Politik,Yogyakarta: Gadjah Mada University Press

Rahman, A.H.I, 2007, Sistem Politik Indonesia, Yogyakarta: Graha Ilmu,

Robert Clark, William, Matt Golder, Sona nadenichek Golder ,2009, Principles of Comparative Politics, washington : CQ Press,p. 3

\section{Jurnal :}

Alamsyah, Nur, M. , "Budaya Politik dan Iklim Demokrasi Di Indonesia", Jurnal Academia FISIP UNTAD Vol 2 No 02 Oktober 2010, hal 415.

Betata, H.C.. "What is missing in measures of women's empowerment? ",Journal of Human Development, 7(2) (2007), 221-241.

Jurnal Sosial Demokrasi edisi 6 tahun 2, Juni Agustus 2009 diakses melalui http://library. fes. de/pdffiles/bueros/indonesien/07003/jurn al\%20edisi\%206\%20kirim. pdfakses pada tanggal 11 Februari 2016. 
Piayura, Premsak Dr, Dusadee Ayuwat, "Political Culture in 21st Century Thai Villages, International Conference on Social Science and Humanity",IPEDR Vol. 5, IACSIT, Singapore, p. 247

Romanov, Liza, "The Women of Thailand", Global Majority EJournal, Vol 3, No. 1 (June 2012), pp. 44-60, p. 55

Sidel, John T. , "Social Origins of Dictatorship and Democracy Revisited: Colonial State and Chinese Immigrant in the Making of Modern Southeast Asia," Comparative Politics 40, no. 2 (2008): 127-147.

Schafferer, Christian, "The Parliamentary Election in Thailand, December 2007, Notes on Recent Elections/ Electoral Studies 28 (2009) 141173, p. 167.

Schraufnagel, Scot, Michael Buehler, Maureen Lowry-Fritz, "Voter Turnout in Democratizing Southeast Asia:A Comparative Analysis of Electoral Participation in Five Countries", Taiwan Journal of Democracy, July 2014. P. 6

Sopchokchai, Orapin, "Women's Political Participation in Thailand", TDRI Quarterly Review, Vol. 13 No. 4, December 1998, p. 11-12

Subono, Nur Iman, "Representasi politik perempuan yang lebih bermakna dalam Representasi Politik Perempuan : Sekedar Ada Atau Pemberi Warna", Jakarta, Jurnal Sosial Demokrasi edisi 6 Tahun 2 Juni-Agustus 2009, hal 59.

Susiana, Sali, "Penurunan Keterwakilan Perempuan Dalam Pemilu 2014",
Info Singkat Kesejahteraan Sosial, Vol. VI/No. 10/II/ P3DI/ Mei/2014, hal. 10 dapat diakses melalui http://berkas. dpr. go. id/pengkajian/files/info_singkat/Inf o\%20Singkat-VI-10-II-P3DIApril-2014-11. pdfjam akses 11 Februari 2016

Thamrongthanyawong, Sombat, "The Backgrounds, Political Culture and political Participation of Thai Youth Leaders", NIDA Development Journal, Vol 50 No. 4/2010. p. 8384

\section{Internet :}

Democracy

http://democracyranking. org/wordpress/?page_id=590

Herien Puspitawati Konsep, Teori, dan Analisis Gender, IPB Press, Bogor, hal. likk. fema. ipb. ac. id/v2/images/karyailmiah/gender. pdfdalam karya, diakses tanggal 09 Juni 2015

http://www.th.undp.org/content/thailand/e n/home/ourwork/social_advocacy/s uccessstories/advocacy-forpolitical-equality-puts-undp-innational-spotlight.html diakses pada Selasa, 29 Desember 2015

http://www.ipu.org/parline-e/reports/ThaiHR_B.htm

http://www.republika.co.id/berita/internasi onal/asean/13/12/28/myibarpemilu-thailand-2-februari-diikuti53-partai

http://www.theglobalreview.com/content_ detail.php?lang=id\&id=5813\&type $=2 \#$. VoHdTU-9u $1 \mathrm{~s}$

Indar Parawansa, Khofifah, "Hambatan Terhadap Partisipasi Politik Perempuan Indonesia", dapat 
dilihat dalam http://www. idea. int/publications/wip/upload/CSIndonesia. pdf diakses pada tanggal 10 September 2015.

Keterwakilan Perempuan http://www. berdikarionline.com/editorial/2013 0422/keterwakilan-perempuan-diparlemen.html\#ixzz3Zsnjzu88, diakases pada 8 Mei 2015

Kuswandi, Aos, "Membangun Gerakan Budaya Politik Dalam Sistem Politik Indonesia", hal. 40. Dapat dilihat dalam http://download. portalgaruda.org/article.php?article $=19706 \& \mathrm{val}=1237$ tanggal akses 21 September 2015

repository.usu.ac.id/bitstream/123456789/ 18102/3/Chapter\%20II. pdf diakses tanggal 09 Juni 2015

Rettnowati, Yuni ,Hambatan Budaya pada Partisipasi Politik Perempuan, Hal. 158file:///C:/Users/User/Download s/95Hambatan\%20Budaya\%20Ter hadap\%20Partisipasi\%20Perempua n. pdf jam akses 11 februari 2016

Sinpeng, Aim, “Thailand's Electoral Rules",30 May 2011, East Asia Forum Quarterly October December 2015, http://asiapacific. anu. edu. au/newmandala/2011/05/30/thailan ds-electoral-rules/

Sonsri,. Gamolporn Dr, Analysis of Thai Political culture factors as Motivator Influencing the Perfromance of Municipal Employees in Public Service Delivery,p. 6-8 unpan1. un. org/intradoc/groups/public/. . . /unpan027465. p. .

Thailand General Election, Report of the International Election
Listyaningsih, Partisipasi Perempuan

VOLUME 16. NOMOR 2. APRIL 2017

Publik Vol 1 No. 2 Desember 2010, Hal. 144 dapat dilihat dalam download. portalgaruda. org/article. php? article $=49017 \&$ val $=4026$ Diak ses tanggal 09 Juni 2015.

Munadi, "Budaya Politik Masyarakat Samin (SEDULURSIKEP) Studi Kasus: Di Dukuh Mbombong Desa Baturejo Kecamatan Sukolilo Kabupaten Pati Provinsi Jawa Tengah", hal. 2 Dapat dilihat dalam file:///C:/Users/User/Downloads/60 70-13089-1-PB. pdftanggal akses 21 September 2015

Observation Mission By The Asian Network for Free Elections (ANFREL) p. 25 anfrel. org/ThaiEOMReport_Edit4_final_edit. p 